\title{
Additional Coumarins from Kielmeyera reticulata
}

\author{
Frederico G. Cruz ${ }^{*, a}$, Luciana de M. Moreira ${ }^{a}$, Nelson A. S. Santos ${ }^{a}$ and Maria L. S. Guedes ${ }^{b}$ \\ ${ }^{a}$ Instituto de Química, Universidade Federal da Bahia, ${ }^{b}$ Instituto de Biologia, Universidade Federal da Bahia, \\ 40170-290, Salvador-BA, Brazil
}

\begin{abstract}
Do extrato hexânico e da fase extraída com diclorometano do extrato metanólico de Kielmeyera reticulata foram isoladas três novas 4-fenilcumarinas, 5,7-diidroxi-6-(2'-hidroxi-3'-metil-3'-butenil)8-(4"-cinamoil-3"'-metil-1"-oxobutil)-4-fenilcumarina, 7-hidroxi-8-(4"-cinamoil-3"'-metil-1"oxobutil)-2'-(2-hidroxiisopropil)diidrofurano $\left(5^{\prime}, 4^{\prime}: 5,6\right)$-4-fenilcumarina e 5,7-diidroxi-8-(4'”cinamoil-3"-metil-1"'-oxobutil)-4-fenilcumarina, além das substâncias já conhecidas, 7-hidroxi-8(4"'-cinamoil-3"'-metil-1"'-oxobutil)-2',2'-dimetilpirano(6',5':5,6)-4-n-propilcumarina, 5-hidroxi-6(4"'-cinamoil-3"'-metil-1"'-oxobutil)-2',2'-dimetilpirano(6',5':7,8)-4-n-propilcumarina, $\delta$-tocotrienol e 2,3-metilenodioxixantona.
\end{abstract}

Three new 4-phenylcoumarins, 5,7-dihydroxy-6-(2'-hydroxy-3'-methyl-3'-butenyl)-8-(4"'cinnamoyl-3"'-methyl-1"-oxobutyl)-4-phenylcoumarin, 7-hydroxy-8-(4"-cinnamoyl-3"-methyl-1"oxobutyl)-2'-(2-hydroxyisopropyl)-dihydrofurano(5',4':5,6)-4-phenylcoumarin, and 5,7dihydroxy-8-(4"-cinnamoyl-3"'-methyl-1"-oxobutyl)-4-phenylcoumarin, along with the known 4n-propylcoumarins, 7-hydroxy-8-(4"-cinnamoyl-3"-methyl-1"'-oxobutyl)-2',2'-dimethylpyrano $\left(6^{\prime}, 5\right.$ ' :5,6)-4-n-propylcoumarin, 5-hydroxy-6-(4"'-cinnamoyl-3"'-methyl-1"'-oxobutyl)-2',2'dimethylpyrano(6',5':7,8)-4-n-propylcoumarin, the xanthone, 2,3-methylenedioxyxanthone and $\delta$ tocotrienol were isolated from the organic extracts of Kielmeyera reticulata stems .

Keywords: Kielmeyera reticulata, Guttiferae, Clusiacea, 4-phenylcoumarins, 4-propylcoumarins, neoflavonoids

\section{Introduction}

Kielmeyera reticulata is a wild shrub belonging to Guttiferae (Clusiaceae). Its stems were collected in sand dunes (restinga) on the Bahia state coast, Brazil. A previous work reported on the isolation of five prenylated 4phenylcoumarins from this species. ${ }^{1}$ Studies of this genus showed that species from the "cerrado" (savanna) of the Brazilian Central plateau are rich in xanthones, ${ }^{2-7}$ while species from the "restinga" (sand dunes) are rich in prenylated 4-phenyl and 4-alkylcoumarins. ${ }^{1,8}$ Only two species showed xanthones such as prenylated 4-phenyl and 4-alkylcoumarins. ${ }^{9} 10$

\section{Experimental}

\section{General procedures}

UV spectra were obtained on Cary 1-E, Varian in $\mathrm{MeOH}$

* e-mail: fguare@ufba.br and $\mathrm{MeOH} / \mathrm{NaOH}$. EIMS were taken with direct probe insert at $70 \mathrm{eV}$ on HP 5973. NMR spectra were obtained from Gemini 300-Varian in $\mathrm{CDCl}_{3}$ solution with TMS as internal reference standard. Rotations were determined with 241 Perkin Elmer polarimeter.

\section{Plant material}

Stems of $K$. reticulata Saad were collected in the sand dunes of Parque Metropolitano do Abaeté, Salvador, Bahia, Brazil, in January 1992. A voucher specimen, 027415, is deposited in the "Alexandre Leal Costa" Herbarium, Instituto de Biologia, Universidade Federal da Bahia, Salvador, Bahia, Brazil.

\section{Extraction and isolation}

The dried stems $(3.4 \mathrm{~kg})$ were first extracted with hexane and after with methanol. The hexane extract $(37.1 \mathrm{~g})$ was submitted to silica gel (40-63 $\mu \mathrm{m}$, Merck) column chromatography using hexane/EtOAc gradient. Several 
fractions were rechromatographed on silica gel CC using hexane/EtOAc gradient to give $\mathbf{1}(276.9 \mathrm{mg}), \mathbf{2}$ (123.0 mg), 7-hydroxy-8-(4"-cinnamoyl-3"-methyl-1"-oxobutyl)2',2'-dimethylpyrano(6',5':5,6)-4- $n$-propylcoumarin (17.8 mg), 5-hydroxy-6-(4"'-cinnamoyl-3"-methyl-1"-oxobutyl)$2^{\prime}, 2^{\prime}$-dimethylpyrano(6',5':7,8)-4-n-propylcoumarin (26.9 $\mathrm{mg}$ ) and $\delta$-tocotrienol $(288.3 \mathrm{mg})$. The methanol extract was submitted to partition with $\mathrm{MeOH} / \mathrm{H}_{2} \mathrm{O} / \mathrm{CH}_{2} \mathrm{Cl}_{2}$ yielding a $\mathrm{CH}_{2} \mathrm{Cl}_{2}$ phase $(32.1 \mathrm{~g})$ that was submitted to silica gel column chromatography using hexane/acetone gradient. Several fractions were rechromatographed on silica gel CC using hexane/acetone gradient to give $\mathbf{3}$ (30.4 $\mathrm{mg})$ and 2,3-methylenedioxyxanthone $(6.7 \mathrm{mg})$.

5,7-dihydroxy-6-(2'-hydroxy-3'-methyl-3'-butenyl)-8-(4"'cinnamoyl-3"-methyl-1"-oxobutyl)-4-phenylcoumarin, (1)

$\mathrm{C}_{34} \mathrm{H}_{32} \mathrm{O}_{8}$. Amorphous yellow-greenish solid. NMR: see Tables 1 and 2. EIMS $m / z$ (rel. int.): $568[\mathrm{M}]^{+}$(1), 349 (99), $293(59), 131$ (100), $103(54)$. $[\alpha]^{24}{ }_{\mathrm{D}}-61.0^{\circ}\left(c 0.410 \mathrm{CHCl}_{3}\right)$.

7-hydroxy-8-(4"-cinnamoyl-3"'-methyl-1"'-oxobutyl)-2'-(2hydroxyisopropyl) dihydrofuran-( $\left.5^{\prime}, 4^{\prime}: 5,6\right)-4$ phenylcoumarin, (2)

$\mathrm{C}_{34} \mathrm{H}_{32} \mathrm{O}_{8}$. Amorphous yellow-greenish solid. NMR: see Tables 1 and 2. EIMS $\mathrm{m} / \mathrm{z}$ (rel. int.): 420 [M$\left.\mathrm{C}_{6} \mathrm{H}_{5} \mathrm{C}_{2} \mathrm{H}_{2} \mathrm{CO}_{2} \mathrm{H}\right]^{+}$(7), 365 (9), 361 (8), 347 (8), 293 (9), $131(100), 59(30) .[\alpha]^{24}{ }_{\mathrm{D}}+92.3^{\circ}\left(c 0.370 \mathrm{CHCl}_{3}\right)$.

5,7-dihydroxy-8-(4"'-cinnamoyl-3"-methyl-1"'-oxobutyl)4-phenylcoumarin, (3)

$\mathrm{C}_{29} \mathrm{H}_{24} \mathrm{O}_{7}$. Amorphous yellow-greenish solid. NMR: see
Tables 1 and 2. EIMS $m / z$ (rel. int.): $484[\mathrm{M}]^{+}$(2), 336 (39), 321 (100), 281 (44), 131 (63). $[\alpha]^{24}+21.74^{\circ}(c 0.460$ $\mathrm{CHCl}_{3}$ ).

\section{Results and Discussion}

From the hexane extract of $K$. reticulata two new 4phenylcoumarins, 1 and 2, two 4- $n$-propylcoumarins, 7hydroxy-8-(4"-cinnamoyl-3"-methyl-1"-oxobutyl)-2',2'dimethylpyrano(6', 5':5,6)-4-n-propylcoumarin, 5hydroxy-6-(4"-cinnamoyl-3"-methyl-1"'oxobutyl)-2',2'dimethylpyrano( $\left.6^{\prime}, 5^{\prime}: 7,8\right)-4-n$-propylcoumarin, previously isolated from $K$. argentea, ${ }^{8}$ and $\delta$-tocotrienol ${ }^{11}$ were isolated. The $\mathrm{CH}_{2} \mathrm{Cl}_{2}$ phase of the methanol extract yielded a new 4-phenylcoumarin, 3, and 2,3-methylenedioxyxanthone. ${ }^{10}$

Compounds 1, 2, and $\mathbf{3}$ are yellow-greenish amorphous solids and their molecular formulae and structures were established by UV, EI mass spectrometry, ${ }^{1} \mathrm{H}$ and ${ }^{13} \mathrm{C}$ NMR. Complete structural assignments were made by analogy with literature data ${ }^{12-14}$ and by a combination of DEPT, ${ }^{1} \mathrm{H}-{ }^{13} \mathrm{CCOSY}$ one bond and multiple bonds. ${ }^{1} \mathrm{H}$ NMR spectra of $\mathbf{1}, \mathbf{2}$, and $\mathbf{3}$ (Table 1) showed characteristic signals of a $\mathrm{H}-3$ singlet, a 4phenyl group, and one hydroxyl hydrogen (exchangeable with $\mathrm{D}_{2} \mathrm{O}$ ) bonded to an acyl side chain, and a cinnamoyl group. The spectrum of $\mathbf{1}$ showed the additional presence of two broad singlets at $\delta 4.81$ and $\delta 4.92$ assigned to terminal double bond hydrogens, a broad doublet at $\delta 4.27$ assigned to the oxymethine hydrogen H-2', a doublet at $\delta 4.18$ assigned to oxymethylene hydrogens H-4", and at $\delta 3.39$ and $\delta 3.26$, two pairs of doublets of doublets assigned to H-2"a and H2 "b respectively. The hydrogen H-1'a at $\delta 3.04$ was a doublets of doublets (14.6 and $1.4 \mathrm{~Hz}$ ) while $\mathrm{H}-1$ 'b at $\delta 2.73$, was partially overlapped with the multiplet of H-3".

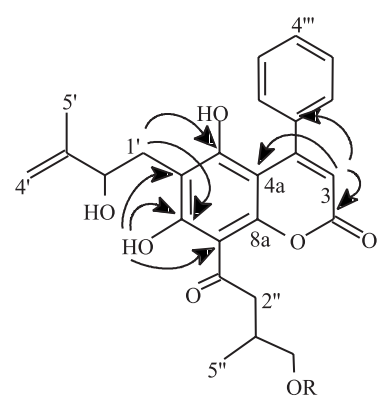

1

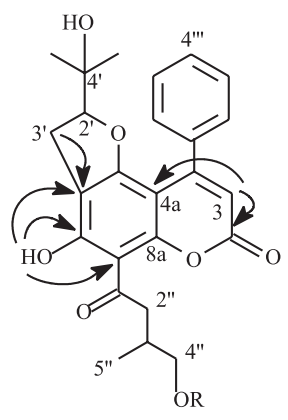

2

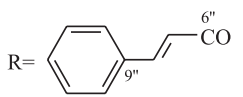

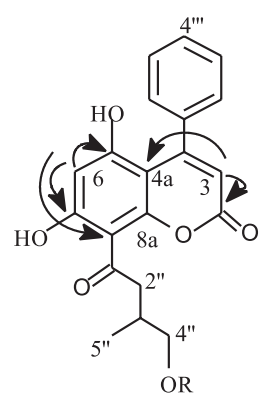

3

Figure 1. Structure of compounds 1, 2, and 3 and some important long range correlations observed in the ${ }^{1} \mathrm{H}-{ }^{13} \mathrm{C}$ COSY spectra (COLOC). 
Table1. ${ }^{1} \mathrm{H}$ NMR data for compounds 1, 2, and $3\left(300 \mathrm{MHz}, \mathrm{CDCl}_{3}\right)$

\begin{tabular}{|c|c|c|c|}
\hline $\mathbf{H}$ & 1 & 2 & 3 \\
\hline 3 & $5.97,1 \mathrm{H}, \mathrm{s}$ & $6.08,1 \mathrm{H}, \mathrm{s}$ & $6.00,1 \mathrm{H}$ \\
\hline 6 & & & $6.22,1 \mathrm{H}, \mathrm{s}$ \\
\hline 1 'a & $3.04,1 \mathrm{H}, \mathrm{dd}(14.6,1.4)$ & & \\
\hline 1’b & $2.73,1 \mathrm{H}$, overlap & & \\
\hline 2, & $4.27,1 \mathrm{H}$, bd $(8.4)$ & $4.45,1 \mathrm{H}, \mathrm{dd}(9.7,8.9)$ & \\
\hline 3'a & & $2.87,1 \mathrm{H}, \mathrm{dd}(15.4 ; 8.9)$ & \\
\hline 3'b & & $2.99,1 \mathrm{H}, \mathrm{dd}(15.4 ; 9.7)$ & \\
\hline 4'a & $4.81,1 \mathrm{H}, \mathrm{s}$ & & \\
\hline 4'b & $4.92,1 \mathrm{H}, \mathrm{s}$ & & \\
\hline 5, & $1.75,3 \mathrm{H}, \mathrm{s}$ & $0.91,3 \mathrm{H}, \mathrm{s}$ & \\
\hline 6, & & $0.98,3 \mathrm{H}, \mathrm{s}$ & \\
\hline 2”a & $3.26,1 \mathrm{H}, \mathrm{dd}(16.2 ; 6.2)$ & $3.29,1 \mathrm{H}, \mathrm{dd}(16.3 ; 6.2)$ & $3.28,1 \mathrm{H}, \mathrm{dd}(16.5 ; 6.3)$ \\
\hline 2"b & $3.39,1 \mathrm{H}, \mathrm{dd}(16.2 ; 7.1)$ & $3.46,1 \mathrm{H}, \mathrm{dd}(16.3 ; 7.2)$ & $3.41,1 \mathrm{H}, \mathrm{dd}(16.5 ; 6.8)$ \\
\hline 3” & $2.68,1 \mathrm{H}$, overlap & $2.71,1 \mathrm{H}, \mathrm{m}$ & $2.69,1 \mathrm{H}, \mathrm{m}$ \\
\hline $4 "$ & $4.18,2 \mathrm{H}, \mathrm{d}(5.9)$ & $4.24,2 \mathrm{H}, \mathrm{m}$ & $4.21,2 \mathrm{H}, \mathrm{m}$ \\
\hline $5 ”$ & $1.13,3 \mathrm{H}, \mathrm{d}(6.7)$ & $1.18,3 \mathrm{H}, \mathrm{d}(7.0)$ & $1.16,3 \mathrm{H}, \mathrm{d}(6.8)$ \\
\hline $7 \%$ & $6.38,1 \mathrm{H}, \mathrm{d}(16.2)$ & $6.42,1 \mathrm{H}, \mathrm{d}(16.1)$ & $6.41,1 \mathrm{H}, \mathrm{d}(16.0)$ \\
\hline $8 ”$ & $7.61,1 \mathrm{H}, \mathrm{d}(16.2)$ & $7.64,1 \mathrm{H}, \mathrm{d}(16.1)$ & $7.65,1 \mathrm{H}, \mathrm{d}(16.0)$ \\
\hline Phenyl (Cinnamoyl) & $7.36,3 \mathrm{H}, \mathrm{m} 7.49,2 \mathrm{H}, \mathrm{m}$ & $7.44,3 \mathrm{H}, \mathrm{m} \quad 7.53,2 \mathrm{H}, \mathrm{m}$ & $7.36,3 \mathrm{H}, \mathrm{m} 7.52,2 \mathrm{H}, \mathrm{m}$ \\
\hline 4-phenyl & $7.28,2 \mathrm{H}, \mathrm{m} 7.36,3 \mathrm{H}, \mathrm{m}$ & $7.30,2 \mathrm{H}, \mathrm{m} \quad 7.38,3 \mathrm{H}, \mathrm{m}$ & $7.36,2 \mathrm{H}, \mathrm{m} 7.46,3 \mathrm{H}, \mathrm{m}$ \\
\hline 7-OH & $14.62,1 \mathrm{H}, \mathrm{s}$ & $14.10,1 \mathrm{H}, \mathrm{s}$ & $14.00,1 \mathrm{H}, \mathrm{s}$ \\
\hline
\end{tabular}

Values in parentheses indicate coupling constants $J(\mathrm{~Hz})$.

The ${ }^{13} \mathrm{C}$ NMR spectrum (Table 2) confirmed the presence of the groups above and their positions on the 4phenylcoumarin nucleus were unequivocally assigned by ${ }^{1} \mathrm{H}-{ }^{13} \mathrm{C}$ long range correlations (COLOC). Thus, the correlations between the signal at $\delta 5.97(\mathrm{H}-3)$ with the carbon signals at $\delta 159.4,139.7$ and 102.3 permitted to assign these resonances to C-2, C-1'”, and C-4a, respectively. The correlations of the signal at $\delta 14.62(\mathrm{OH}$ bonded) with the carbon signals at $\delta 166.7$ (C-7), 110.1 (C-6) and 103.9 (C-8) made possible to place this hydroxyl group at C-7. The group 2'-hydroxy-3'-methyl-3'-butenyl was located at C-6 due to the observed correlations between the signal at $\delta 3.04\left(\mathrm{H}-1^{\prime}\right)$ with the carbons at $\delta$ 166.7 (C-7), 161.1 (C-5), and 110.1 (C-6). Therefore, the 4"-cinnamoyl-3"-methyl-1"-oxobutyl group was placed at C-8. This assumption was corroborated by the observation of a low bathochromic shift ( 387 to $392 \mathrm{~nm}$ ) of the longer wavelength band in the UV spectrum after alkali addition. ${ }^{13}$

The signals in the ${ }^{1} \mathrm{H}$ NMR spectrum of $\mathbf{2}$ (Table 1 ) at $\delta$ $4.45,2.87$ and 2.99 , in addition to the signals at $\delta 93.3$ (C$\left.2^{\prime}\right), 72.1$ (C-4'), 25.3 (C-5') and 23.9 (C-6') in the ${ }^{13} \mathrm{C}$ NMR spectrum (Table 2), suggested the presence of the 2'-(2hydroxyisopropyl)dihydrofuran system. This group was confirmed by ${ }^{1} \mathrm{H}^{-13} \mathrm{C}$ long range correlations and by the presence of an abundant ion at $m / z 59\left(\mathrm{C}_{3} \mathrm{H}_{7} \mathrm{O}^{+}\right)$in the mass spectrum, which is characteristic of that system. ${ }^{14}$ The positions of the groups in aromatic coumarin ring were deduced by long range correlations (COLOC). The
Table 2. ${ }^{13} \mathrm{C}$ NMR data for compounds $\mathbf{1}, \mathbf{2}$, and $\mathbf{3}\left(75 \mathrm{MHz}, \mathrm{CDCl}_{3}\right)$

\begin{tabular}{|c|c|c|c|}
\hline $\mathbf{C}$ & 1 & 2 & 3 \\
\hline 2 & 159.4 & 159.2 & 158.8 \\
\hline 3 & 111.9 & 111.7 & 111.8 \\
\hline 4 & $156.8^{*}$ & $155.4^{*}$ & $157.7^{*}$ \\
\hline $4 a$ & 102.3 & 99.3 & 101.2 \\
\hline 5 & 161.1 & 162.9 & 160.4 \\
\hline 6 & 110.1 & 110.6 & 101.0 \\
\hline 7 & 166.7 & 164.0 & 168.4 \\
\hline 8 & 103.9 & 105.7 & 104.8 \\
\hline $8 \mathbf{a}$ & $156.4^{*}$ & $157.7^{*}$ & $155.0^{*}$ \\
\hline 1, & 28.8 & - & - \\
\hline 2, & 76.9 & 93.3 & - \\
\hline 3, & 146.2 & 27.3 & - \\
\hline 4, & 110.6 & 72.1 & - \\
\hline 5, & 18.4 & 25.3 & - \\
\hline 6 , & - & 23.9 & - \\
\hline $1 ”$ & 204.6 & 205.4 & 204.4 \\
\hline 2" & 48.5 & 49.1 & 48.5 \\
\hline 3" & 30.0 & 30.8 & 30.9 \\
\hline $4 "$ & 68.9 & 69.4 & 68.9 \\
\hline $5 "$ & 17.3 & 17.9 & 17.3 \\
\hline 6" & 167.1 & 167.4 & 167.2 \\
\hline 7" & 117.9 & 118.7 & 117.9 \\
\hline $8 ”$ & 144.8 & 145.2 & 144.9 \\
\hline $9 "$ & 134.3 & 135.1 & 134.4 \\
\hline $10 "-14 "$ & 128.1 & 128.7 & 128.8 \\
\hline $11 "-13 "$ & 128.8 & 129.4 & 128.9 \\
\hline $12 "$ & 130.3 & 130.7 & 130.2 \\
\hline $1, "$ & 139.7 & 138.6 & 137.4 \\
\hline $2, " 6, "$, & 127.1 & 128.7 & 127.3 \\
\hline $3, "-5$, & 127.6 & 129.4 & 128.1 \\
\hline 4, & 128.2 & 128.00 & 129.6 \\
\hline
\end{tabular}

* This signals may be interchangeable 
correlations observed between the signal at $\delta 6.08(\mathrm{H}-3)$ with the signals at $\delta 159.2$ and $\delta 99.3$ permitted the assignment of these resonances to carbons C-2 and C-4a, respectively. The correlations of the resonance at $\delta 14.10$ (OH bonded) with the signals at $\delta 105.7$ (C-8), 110.6 (C-6) and $164.0(\mathrm{C}-7)$ and those at $\delta 2.87$ (H-3'a) and $2.99(\mathrm{H}-$ 3 'b) with $\delta 110.6$ (C-6) made evident the location of the bonded hydroxyl at C-7, the 2'-(2-hydroxyisopropyl)dihydrofuran ring at C-5 and C-6 and the 4"-cinnamoyl3"-methyl-1"-oxobutyl group at C-8. The UV spectrum of 2 after alkali addition showed a bathochromic shift (348 to $379 \mathrm{~nm}$ ) of the longer wavelength band. The observed shift was lower than the obtained with a similar compound with the acyl side chain at C-6 (348 to $428 \mathrm{~nm}) .{ }^{15}$ In conclusion, the UV data corroborated with the location of the acyl side chain at C-8.

The long-range correlation observed in the ${ }^{1} \mathrm{H}-{ }^{13} \mathrm{C}$ COSY spectrum of $\mathbf{3}$, between the signal at $\delta 6.00(\mathrm{H}-3)$ and the carbon signal at $\delta 101.2$ allowed the assignment of this signal to C-4a. The correlations of the hydrogen signal at $\delta 6.22$ with the carbon signals at $\delta 160.4$ (C-5), $168.4(\mathrm{C}-7)$ and 104.8 (C-8) allowed the placement of this hydrogen at C-6 and consequently the 4"-cinnamoyl-3"methyl-1"-oxobutyl side chain was placed at C-8. The acyl side chain at C-8 was confirmed by the low bathochromic shift (382 to $388 \mathrm{~nm}$ ) of the longer wavelength band in the UV spectrum after alkali addition.

\section{Acknowledgements}

Authors are grateful to Cecília Veronica Nuñes (IQUSP) for recording the $\alpha_{\mathrm{D}}$ values, as well as to CNPq for the MSci. fellowships awarded to L. M. M. and N. A. S. S. This work was supported by grants from CNPq and FINEP.

\section{References}

1. Cruz, F. G.; Moreira, L. de M.; David, J. M.; Guedes, M. L. S.; Chávez, J. P.; Phytochemistry 1998, 47, 1363.

2. Gottlieb, O. R.; Magalhães, M. T.; Stefani, G. M.; Tetrahedron 1966, 22, 1785.

3. Gottlieb, O. R.; Mesquita, A. A. L.; Nagem, T. J.; Phytochemistry, 1971, 10, 2253.

4. Gottlieb, O. R.; Mesquita, A. A. L.; Oliveira, G. G.; Melo, M. T.; Phytochemistry 1970, 9, 2537.

5. Gottlieb, O. R.; Mesquita, A. A. L.; Silva, E. M.; Melo, M. T.; Phytochemistry 1969, 8, 665.

6. Gottlieb, O. R.; Stefani,G. M.; Phytochemistry 1970, 9, 453.

7. Cortez, D. A.; Young, M. C. M.; Marston, A.; Wolfender, J-L.; Hostettmann, K.; Phytochemistry 1998, 47, 1367.

8. Cruz, F. G.; Santos, N.A. S.; David, J. M.; Guedes, M. L. S.; Chávez, J. P.; Phytochemistry 1998, 48, 703.

9. Nagem, T. J.; Silva, M. A.; Phytochemistry 1988, 27, 2961.

10. Cruz, F.G.; da Silva-Neto, J. T.; Guedes, M. L. S.; J. Braz. Chem. Soc. 2001, 12, 117.

11. Monache, D. F.; Marta, M.; Mac-Qhae, M. M.; Nicoletti, M.; Gazz. Chim. Ital. 1984, 114, 135.

12. Crichton, E. G.; Waterman, P. G.; Phytochemistry 1978, 17, 1783.

13. Crombie, L.; Jones, R. C. F.; Palmer, C. J.; J. Chem. Soc., Perkin Trans. I 1987, 317.

14. Carpenter, I.; McGarry, E. J.; Scheinmann, F.; J. Chem. Soc. (C), 1971, 3783.

15. Bandaranayake, W. M.; Selliah, S. S.; Sultanbawa, M. U. S.; Games, D. E.; Phytochemistry 1975, 14, 265.

Received: April 8, 2002 Published on the web: September 6, 2002 